\title{
Staff and Their Responsibilities in Radiology Center
}

\author{
Aabhilasha Pareek* \\ Jayoti Vidyapeeth Women's University, Jaipur
}

Submission: April 27, 2018; Published: May 01, 2018

"Correspondence Address: Aabhilasha Pareek, Radiation student, Jayoti Vidyapeeth Women's University, Jaipur, Rajasthan

\section{Introduction}

Imaging center or radiology center is a facility with the equipment to provide various types of radiologic images. Radiology is now the key diagnostic tool for many diseases and has an important role in monitoring treatment and predicting outcome. It has a number of imaging modalities which have differing physical principles of varying complexity. There are various staffs in a radiology center with their respective responsibilities.

\section{Staffs in Radiology Center \\ i. Radiologist \\ ii. Radiographer or Technologist \\ iii. Nurses and Ward boys \\ iv. Reception staff \\ v. Pharmacy staff \\ vi. Cleaning staff \\ vii. Guard and security staff}

\section{Responsibilities of Each Staff}

\section{Radiologist}

Radiologist is a physician who is specialized in capturing and analyzing medical images. Radiologist is the head of the department. Work of radiologist includes:

i. Ensures availability of every equipment.

ii. Arrange staffing.

iii. Check all the imaging and diagnostic procedures.

iv. Acting as an expert consultant to your referring physician (the doctor who sent you to the radiology department or clinic for testing) by aiding him or her in choosing the proper examination, interpreting the resulting medical images, and using test results to direct your care.

v. Treating diseases by means of radiation (radiation oncology) or minimally invasive, image-guided therapeutic intervention (interventional radiology). vi. Correlating medical image findings with other examinations and tests.

vii. Directing radiologic technologists (personnel who operate the equipment) in the proper performance of quality exams.

viii. Recommending further appropriate examinations or treatments when necessary and conferring with referring physicians.

\section{Radiographer}

Radiographers are technicians who deals with patients and operates the equipment. Radiographers perform various functions in their effort to perfectly diagnose patients' diseases. Major duties, tasks, and responsibilities commonly assigned to the role radiographer include:

a. Evaluate patients' medical condition and history to determine most suitable radiographic technique for diagnosis.

b. Interact with patients to offer them psychological support and address their concerns regarding an imaging procedure.

c. Adjust diagnostic equipment to deliver accurate amount of radiation to patients.

d. Operate complex medical instruments such as MRIs, CT scanners, X-ray, ultrasound, and several other imaging devices.

e. Liaise with oncologists and physicians to plan treatment for cancer patients.

f. Direct and supervise the activities of radiography assistants and trainee radiographers.

g. Maintain proper records of patient details ensuring confidentiality of sensitive information.

h. Follow up on patients after treatment to track the progress of recovery and ensure patients show no signs of radiation side effect. 
i. Explain to patients and their family the details of a procedure and ways to manage possible side effects.

j. Regularly inspect diagnostic equipment to ensure they are functional and operate efficiently.

k. Assist oncologists and physicians during complex radiological examinations.

l. Ensure compliance with health and safety guidelines to minimize risk of exposure to ionizing radiation.

m. Correctly position patients prior to X-ray imaging in order to obtain high quality films.

n. Use portable devices to conduct diagnostic scans on patients who can't move to the radiology unit.

\section{Nurses and Ward Boys}

The roles of nurses and ward boys in a radiology center require a high level of knowledge, expertise and independence because the department provides services to wide variety of patients with diverse needs. Their duties include.

i. The nurses inform the technologists or radiologists about any unusual patient needs and perform specialized nursing duties.

ii. Devote a lot of time to quality improvement and infection control program.

iii. Helps in transfer of patients.

iv. Prepares the patient for diagnosis.

v. Provides a gown to the patient.

\section{Reception Staff}

Duties of a reception staff includes:

a. Reception staff checks the patient in for imaging exams.

b. See the reports and pass free receipt and prescription to the radiographer.

c. Co-ordinate scheduled imaging.

d. Provides friendly, accurate and timely services.

e. Fixes the appointments of patients with physicians and technicians.

\section{Pharmacy Staff}

Responsibilities include:

i. Pharmacy staff should take care of the contrast media which is used in imaging.

ii. Apart from the care function of dispensing prescription medicines and supplies includes working with other medical personnel to provide treatment and advice to patient.

iii. Should record the patient history relating to medical issues and contrast media issues.

iv. They should ensure safe and secure storage of all medicines and contrast.

v. Preparation and sterilization of injectable medicines.

vi. Filling and labelling of containers of contrast media used in procedures of imaging.

\section{Cleaning Staff}

Duties include:

a. Must look after the cleaning of floors, benches, chairs, tables and machines as well.

b. Good quality sterilizing products will be used in cleaning.

\section{Guard and Security Staff: Responsibilities includes}

i. The security or safety staff looks after the patient's and equipment security.

ii. The guards provide security to the radiology center.

iii. Control the CCTV footage and protects the center.

\section{Conclusion}

Every staff in a radiology center has their specific roles and responsibilities. Each staff is very important in an imaging center. The co-ordination of the staff in the center results in the positive outcome and also maintains the standard of the imaging center. Each staff member should be well known with the responsibilities assigned to them. Every staff should maintain a proper and peaceful environment in the radiology center. 
This work is licensed under Creative Commons Attribution 4.0 License

DOI: $10.19080 /$ CTOIJ.2017.10.555789

\section{Your next submission with Juniper Publishers} will reach you the below assets

- Quality Editorial service

- Swift Peer Review

- Reprints availability

- E-prints Service

- Manuscript Podcast for convenient understanding

- Global attainment for your research

- Manuscript accessibility in different formats

( Pdf, E-pub, Full Text, Audio)

- Unceasing customer service

Track the below URL for one-step submission https://juniperpublishers.com/online-submission.php 